UNTAG Law Review (ULREV)

Volume 2, Issue 1, May 2018, PP 10-20

ISSN 2549-4910 (online) \& ISSN 2579-5279 (print)

http://jurnal.untagsmg.ac.id/indeks.php/ulrev/indeks

www.fakhukum.untagsmg.ac.id

\title{
RECONSTRUCTION OF THE LEGALITY PRINCIPLE IN PENAL LAW ENFORCEMENT FOR THE REALIZATION OF JUSTICE
}

\author{
Iskandar Wibawa \\ Lecturer at Faculty of Law, Muria Kudus University \\ Email : iskandar.wibawa@yahoo.com
}

\begin{abstract}
The legality principle is an important principle in the enforcement of penal law in addition to the culpability principle. These two principles are a requirement that must be fulfilled by the person to be penalized. However, law enforcement officers in the Criminal Justice System often only pay attention to the formulation of the legality principle in Article 1 (1) of the Criminal Code (KUHP) than the other principle that is culpability principle. So that court decisions often do not reflect a sense of justice. This is due to the interpretation of the legality principle contained in Article 1 paragraph (1) of the Criminal Code (KUHP) as "lex scripta", "lex stricta" and "lex certa" and also the unformulated culpability principle in the Criminal Code (KUHP). Therefore, it is necessary to reconstruct the meaning of the legality principle so that it is not only understood formally, but materially by regarding the living law referred to Pancasila as a ground norm and constitution of the UUD 1945, the legality principle is not interpreted as a certainty of law but interpreted as the principle of legal certainty. The law is not only interpreted as a written law, but also an unwritten law, so it is expected to bring about a court decision in accordance with the sense of justice. In law enforcement "in abstracto" implemented through formulation policy by penal reform in the formulation of a New Criminal Code (New KUHP), the principle of legality has been interpreted in material term that states that the source of law used by the Criminal Code is written law (Article 1) and unwritten law/ the living law (Article 2), also the culpability principle has been formulated explicitly (Article 38). Based "in abstracto" law enforcement is expected to be implemented "in inconcreto" law enforcement so as to realize court decision in accordance with the sense of community justice.
\end{abstract}

Keywords : Legality Principle, Written Law, Unwritten Law/Living Law, Culpability Principle, Law Enforcement. 


\section{INTRODUCTION}

Indonesia is an independent state since 17 August 1945; but there is a lot of law and registrations from Dutch East Indies still being used. However, it is different from with the use of the law and regulation in the Dutch East Indies era. Since Indonesia is an independent state, all of the constitution is a national law that must be based on Pancasila as a "rechtidee" and Pancasila explanation as a "grundnorm". Therefore progressive steps is needed to apply and enforce Dutch East Indies law products that have been changed be a national law, so it suitable with Pancasila as a "grundnorm" and "rechtidee", and constitution of republic of Indonesia as a "constitution" (written basic law) in the national legal framework.

The law and regulations in associating with the law enforcement must not against and also an explanation of Pancasila and 1945 constitution of the Republic of Indonesia, that are: article 28D verse (1) and article 29 verse (1). Article 28D verse (1) of 1945 constitution of the Republic of Indonesia states:

"Every person shall have the right of recognition, guarantees, protection, and certainty before a just law, and of equal treatment before the law."

Article 29 verse (1) of 1945 constitution of the Republic of Indonesia states:

"The state shall be based upon the belief in the one and only God."

One of the Dutch East Indies law products that is still being used until now is Wetboek van Strafrecht voor Nederlandsch Indie (WvS NI) which based on Act No.1 year 1946 on criminal law is used in Indonesia if not against the status of the independent state, in the name of Wetboek van Strafrecht $(W v S)$ or criminal code. One of the fundamental principles in the criminal code is legality principle that is formulated in the article 1 verse (1) as follows:

"not act shall be punished unless by virtue of a prior statutory penal provision".

If legality principle is considered as a principle stated that activity that can be punished is kind of activity prohibited by the constitution, so that activity is potentially against Pancasila and 1945 constitution of the Republic of Indonesia, specifically article 28D verse (1) and article 29 verse (1), because article 1 verse (1) of criminal code is "legism", that is acknowledge the constitution (written law) as law, that can be used as a legal base is constitution (written law) and do not acknowledge that unwritten law or living law is exist.

District court of Banyumas decree mbah Minah did criminal act of theft by jailed 1 month and 15 days and three months probationary period. Supreme Court of Justice stated that dr. Dewi Ayu Sarsiasy Prawarni, SpOG, Cs proved of guilty legally and convinced did malpractice, resulting a patient named Siska Markatey by cito cesarian section operation caused death at 
RSUP Kandao Malayang Manado, breaks the law of article 359 of criminal law, and sentenced for ten months, although in the judicial review from supreme court states that the prisoner is released with no charge, this case is common phenomenon in the judiciary, that the paradigm often used in criminal justice system is still "legism", not progressively referring to Pancasila and 1945 constitution of the Republic of Indonesia that control legal decision must be based on Pancasila, according to the legal security and justice principle article 28D (verse 1) and based on belief in the one and only God article 29 verse (1).

Progressive reconstruction of legisme article 1 verse (1) of criminal code is needed to make it coherent with Pancasila and 1945 constitution of the Republic of Indonesia that beside the "written law" is also considering the living law, as a kind of the construct (system) of national law. This is imply that the source of law based on Pancasila and 1945 constitution of the Republic of Indonesia is the law and constitutions that is written law and the living law or the unwritten law.

Based on those reasons, this is written a paper entitled Reconstruct the Legality Principle in the Criminal Law Enforcement.

\section{PROBLEMS}

Based on the reasons explained in the preface, the problems are formulated as follows;

1. How the implementation of "legality principle" in the criminal law enforcement nowadays?

2. How the reconstruct of "legality principle" in the criminal law enforcement implemented for the manifesting of the justice?

\section{DISCUSSION}

\section{Implementation Of "Legality Principle" In The Criminal Law Enforcement Nowadays}

The legal system according to Laurence Freedman consists of: legal substance, legal structure, and legal culture. Therefore, national legal system also consists of national legal substance, national legal structure, and national legal culture. Because of that, criminal law system enforcement also consists of criminal law substance, criminal law structure, and criminal law culture.

Reinforcement of criminal law substance nowadays is based on article 1 verse (1) of criminal code, that states "not act shall be punished unless by virtue of a prior statutory penal provision". That article is common called by "legality principle". According to that article the act that can be punished is on act that have conducted in criminal code, and other act outside 
criminal code before. This explanation of legality procedure is called as formal legality procedure explanation. The activity that can be punished is the activity breaking act. Behave contempt of court is the same as behave breaking the law. Law is act. There is no law without act. The one and only source of law is act. This belief is called "legism" paradigm. Law is understood as "lex certa, lex stricta, lex scripta".

The impact of the "legism" paradigm is make the judge belief that his/her judgment is based on the constitution, so sometimes disregard the principle of justice and benefit that is required by law philosophically reflecting of justice, normatively reflecting of certainty, and sociologically reflecting benefit principle.

Decision that only based on the certainty of law based on the constitution are not referred to Pancasila as "grundnorm" and "rechtsidee", and 1945 constitution of the Republic of Indonesia, specifically article 28 is requiring that law enforcement should be based on belief on the supreme of God. Moreover, the act the power, that also reflected on every court decree, on the headline of decree always entitled "in the name of justice based on Believing in one supreme God".

Mbah Minah case that judged by district court of Banyumas doing criminal act of 3 pieces of cacao of PT Rumpun Sari Antan, resulting jailed 1 moth and 15 days and 3 moths probationary period is one of case reflect that judge only referred to the formal legality. Law enforcement officer with the positivism paradigm belief that law is real exist and written in the constitution. Code penal is legism, stating that law is written (in the constitution); criminal act is act formulated by the constitution. This is also referred by the explanation by the chairman of the panel of judges (Muslich) stating that mbah Minah act legally and convincingly proven guilty of committing theft against article 362 of code penal, and there is no forgiving reason can be used to prove of her innocence. However, because of the blindness of the act, the age of the elderly, and there is no significant lost of PT Rumpun Sari Antan, panel of judges only sentencing probationary period. Belief that only belief on law certainty is formulated only in the written law (constitution) potentially ignoring of justice and benefit, because against the living law and local wisdom. Based on local wisdom Mbah Minah act is not considered as criminal act, that is stated by the cultural observer. Based on the interview with Widodo Dwi Putro, he stated it is common for the villagers in Banyumas to take a few amount of seed without permission; there is no problem with that act; while if asking politely, even given the best seeds. (Widodo Dwi Saputro, 2011, page 176).

Case of dr. Dewi Ayu Sariarsy Prawarni, SpOG, Cs that is failed while doing opration (cito secsio sesaria) to her patient, Siska Markatey in RSUP Kandao Malayang Manado, that causing death of the patient, and also legally and convincingly proven guilty causing of 
someone that formulated in the article 359 of code penal, by cassation judges lead by Artidjo Alkostar and sentenced 10 months of penal. This is a booming case, this case leading a demonstration by doctors and health workers in the all over the state, and only referred to the law of certainty and disregard benefit principle and justice principle.

From those two cases, can be concluded that the judge of the district court of Banyumas in mbah Minah case and cassation judge in Supreme Court in dr. Ayu cs case use the positivism paradigm, legism ideology, so that only emphasizing in the certainty of formal law as formulated in the constitution and disregard principle of justice and the principle of benefit; where there are three aspects should be counted, that is philosophically realizing of justice, certainty normatively, and there is benefit sociologically.

Positivist or Legist only considering the norms that is only the positively as constitution is qualified as law. This is something that stated by an Austrian jurist named Hans Kalsem, as pure law or doctrine ("reine rechtslehre"). That legist puritan people, always claimed that the national law that have been materialized as a justice is really have its own character, sui generis, and and can exist and grow based its own legism. The regulation is the only base of the law, that formally always being a reference and always being used in every law enforecement. (Soetandyo Wignyo Soebroto, 2011, PDIH UNDIP).

\section{The Reconstruction Of "Legality Principle" In The Criminal Law Enforcement Implemented For The Manifesting Of The Justice}

Developing of criminal law is one of the legal substance development, that is when it will be developed should be involving legal structure development, that are integrated criminal justice system development and legal culture development.

The development of criminal law system in the legal substance field consists of: developing substantive criminal law, developing formal criminal law, and also developing the criminal law.

The idea of the need of the law in the society is stated by criminal law experts. Those are:

a. Paul Scholten state that law is needed to manifesting the value of the justice.

b. Pompe belief that in the law contain value of belief.

c. Sudarto state that law contains value of affection.

d. Barda Nawawi Arif said that in the law contain value of balance.

According to the experts, developing of criminal law that wants to be developed should be arranged progressively so that can be reached: 

a. value of justice
b. value of belief
c. value of affection, and
d. value of balance

Pancasila, the Indonesian state philosophy containing some values, those are:

a. Value of justice based on the value referred to the fifth verse of Pancasila.

b. Value of beliefe in, is implementation of value that conducted from the first verse of Pancasila.

c. Valaue of affection id the implementation of the second verse of the Pancasila.

d. Value of balance is the implementation of the values contained in the verses of the Pancasila, that are the balance of the value of belief in, humanism, unity and diversity, democracy and justice.

The development of the criminal law that is part of the development of the national system law, in the implementation value of balance, those are:

a. The balance of the values in the Pancasila (belief in, humanism, unity, and diversity in order nationalism, democracy, and justice).

b. The balance between the aim of the social welfare and social defense as one of the efforts to realize the national development.

c. Focus on to the national and global views.

d. Realize Indonesia included in the law family “Traditional and Religious Law System”.

The law enforcement in order to realize the law justice can be interpreted as the law enforcement based on Pancasila, that one of the views is based on the belief in. therefore, the law must be manifesting justice based the supreme of God. The justice belief in the supreme of God is the justice based on the guidance and theories of the supreme of God.

Manifesting the justice based on the supreme of God have been mandated in the regulations, those are:

a. Article 29 verse (1) 1945 constitution of the Republic of Indonesia:

"The state shall be based upon the belief in the one and only God."

b. Article 8 verse (3) No. 16, 2004 about Judiciary: 
"In the name of justice and truth based on Belief in the one supreme god, the prosecutor doing his job with clear and convincing evidence".

c. Article $1\left(1^{\text {st }}\right)$ Act No. 48, 2009 about Judicial Power:

Judicial power is the authority of the independence state to contempt justice and law based on Pancasila and 1945 constitution of the Republic of Indonesia.

d. Article 2, Act No. 48, 2009 about Judicial Power:

(1) Judicature held in order to implement the justice based on Believing in one supreme god.

(2) Judicature state applying and enforcing law and justice based on Pancasila

Based on that regulation above, it is can be concluded that it is a certain matter to the law enforcement officer (investigator, prosecutor, judge, executor, and attorney) to actualize the justice values based on Belief in one supreme god, not only based on legal regulation.

Pancasila as "rechsidee" with its first verse, belief in the supreme of god must implemented on the law enforcement, because of as a "rechsidee"- Pancasila is a "grundnorm" to other regulations below. Pancasila as a "grundnorm" formed in the fourth paragraph of Preambule of 1945 constitution of the Republic of Indonesia.

The experts also have certain opinion about the importance of manifesting "justice" based on "Belief Supereme of God". Those are:

a. Moelyanto:

In our state that based on Pancasila, with the existence of supreme god verse, in all of science that not included divinity is an incomplete science (Barda Nawawi Arief, 2011, page 54).

b. Notohamidjojo:

"Jurist responsibility is to bring spirituality to the law, an science to the juridic evaluation must in depth and be based on concientia (value of truth, justice, honesty, affection to others, etc). Ethical religious norms must be a normative or imperative aspect of the law state".

c. Hazairin:

"In the Republic Indonesia, it is cannot be happened or ruled, anything that against the Islamic rules for the Muslims, or Christianity rules for the Christians/Catholics, or Balinese Hindu for the Balinese Hindu people, or against moral values to the Buddhists" (Hazairin, 1985, page 34). 
d. Barda Nawawi Arief:

"The law studies without religious/spiritual study (spiritual values) is incomplete, unstable, and even danger. Criminal law studies that only focused in normative studies and not including the other values studies, is a partial, unstable, and even can be danger studies" (Barda Nawawi Arief, page 55).

e. T.D Singh

"Great thinkers and philosophers of the world reveal that a scientific knowledge and religious wisdom will be able to solve many problems in our day-to-day life".

“.... Along with the explosive expansion of science and technology there is also a rapid deterioration of the quality of life. Hence, there is immediate need to include applied spiritual knowledge and spiritual technology in our daily life...."

The justice based on belief in one supreme of God, means justice based on god rules. The god rules in Islam are stated in the holy Quran. There are:

a. An-Nisa verse 58:

"Surely Allah commands you to make over trust to their owner and that when you judge between people you judge with justice. Surely Allah admonishes you with what is excellent: surely Allah is seeing. Hearing".

b. An-Nisa verse 135:

"O, you who belief! Be main toiners of justice, bears of the witness of Allah's sake, though it may be against your own selves or (your) parents or near relatives. If he be rich or poor, Allah is nearer to them both. In compassion: therefore do not follow (your) low desires, less you deviate: and if swerve or turn aside, then surely Allah is aware of what you do".

c. Al-Maidah verse 8

"O you who belief! Be upright for Allah, bearers of witness with justice, and let not hatred of a people incite you not to act equitably, that is nearer to piety, and be careful of (your duty to). Allah: surely Allah is aware of what you do".

d. Al-Maidah verse 42

"and if you judge between them with equality: surely Allah love those who judge equitably".

e. As-Syura verse 15 
"And I am commanded to do justice between you. Allah is our lord and your lord. We shall have our deeds and you shall have your deeds".

According to the holy Quran verses, we can conclude that Allah demanding to created:

- Equality/non-discriminative principle

- Objectivity principle/non-subjective

- Non-favoritism/non-nepotism principle

- Fairness/impartial principle

According to that sentence, national law enforcement including criminal law development should always refer to Pancasila as "rechsidee" and "grundnorm" which in one of the verses is, "Believing in one supreme god, not only referring to legal regulation".

According to that, it is can be concluded that:

- Criminal law enforcement based on current law ("ius constitutum ") not only rest on period code, moreover only referring to the article 1 verse (1) code pena, that implemented from legality principle/certainty formal law, because can potentially ignoring the implementation of justice and benefit in society; however progressively have a living law concept to manifesting justice based on god divinity, until can manifesting the benefit to the society. Creating justice based on divinity is explicitly stated in 1945 constitution of the Republic of Indonesia., Act no. 16, 2004 about Judiciary, and Act No. 48, 29 about Judicial Power. Thus, legality principle must be materially interpreted (flexible), that is not only based on Penal Code as written law but also progressively looking for other unwritten law (living law), which one of that is based on Believing in one supreme god.

- Criminal law enforcement "in abstracto", that is creating the penal code, should be conducting the formulation of legality principle materially, that is the existence of the living law, that have more ability to manifesting justice based on Pancasila as "rechsidee" and "grundnorm", that is one of the verse is believing in one supreme god. An action can consider as a crime shall preferably not only because of the action against the regulation, but also against the living law. The draft of code penal 2015 formulating criminal act description in article 13, which is generally stated that an act can be concluded as a crime if its stated in regulation and against the living law. Article 13 of draft of Act of code penal 2015 stated:

(1)Criminal act is an act of doing or not doing something that by the regulation stated as a forbidden act, and threatening with sentence. 
(2) To conclude as a criminal act, also have to against law or against the living law in society.

(3) Every criminal act always considered as against the law, except have specific justify reason.

\section{CONCLUSION}

1. The law officer enforcement in criminal justice system nowadays is still applying law certainty principle formally that considering las as "lex certa, lex stricta, lex scripta", legism ideology as formulated in article 1 verse (1) of code penal.

2. Reconstruction of legality principle is done by considering Pancasila as "rechsidee" and "grundnorm" and 1945 constitution of the Republic of Indonesia as a constitution, specifically in article 28D verse (1) and article 29 verse (1) and always included in national legal framework.

\section{RECOMMENDATION}

Reconstruction of nation criminal law with formulate the new code penal until nowadays is not fulfilled yet. Therefore, to manifested the equality of the law. The supreme court as the holder of the law power shall give the guidance to the judges so that in the interpreting of legality principle not only based on regulation but also surely considering the law the living law to optimally manifesting the substantial justice but only procedual justice.

\section{REFERENCES BOOK}

Barda Nawawi Arief, 2011, Pendekatan Keilmuan dan Pendekatan Religius dalam rangka Optimalisasi dan Reformasi Penegakan Hukum (Pidana) di Indonesia; Badan Penerbit Universitas Diponegoro,Semarang;

Hazairin, 1985, Demokrasi Pancasila, Bina Aksara, Jakarta.

Lawrence M Friedman, 1975, “The Legal System - A Social Science Perspective”, Russel Sage Foundation, New York.

Soetandyo Wignyo Soebroto, 2011, Ragam-ragam Konsep dalam Sejarah Perkembangannya, Pergeseran Sejarah Teori Hukum, PDIH UNDIP, Semarang.

Widodo Dwi Putro, 2011, Kritik terhadap Paradigma Positivisme Hukum, Gentha Publishing, Yogyakarta.

\section{REGULATION}

Undang Undang Dasar Negara Republik Indonesia Tahun 1945.

Undang Undang Nomor 1 Tahun 1946 tentang Peraturan Hukum Pidana; 
Iskandar Wibawa : Reconstruction Of The Legality Principle In Penal Law Enforcement ......

Kitab Undang Undang Hukum Pidana (KUHP).

Pelengkap KUHP ( Perubahan KUH Pidana dan UU Pidana di luar KUHP).

UU nomor 8 Tahun 1981 tentang Hukum Acara Pidana.

Undang Undang Nomor 16 Tahun 2004 tentang Kejaksaan.

Undang Undang Nomor 48 Tahun 2009 tentang Kekuasaan Kehakiman.

RUU KUHP Tahun 2015. 